\title{
Challenging the Indonesian Primary Education in Industrial Revolution 4.0 Era
}

\author{
Mahfud M. Gamar \\ Faculty of Education \\ Tadulako University, Indonesia \\ gamarunggul@yahoo.com
}

\author{
M. Saunan Al Faruq \\ Department of Educational Management \\ State University of Malang, Indonesia \\ faruqsae@gmail.com
}

\author{
Lina \\ Department of Educational Management \\ State University of Malang, Indonesia \\ fransiscalina@gmail.com
}

\begin{abstract}
Industrial Revolution 4.0 is the newest change of the formerly existing globalization age constituting the change of transformation, elevation and integration. Primary education has reached its strategic roles in Indonesian national development that it will encounter the challenges of the changing age. The literature reviews have displayed the fact that multi-intelligence-based learning as one of learning strategies which able to facilitate the potentials of the learners. Furthermore, the roles of principals and teachers in learning management are required for supporting to gain the national education purposes.
\end{abstract}

Keywords: primary education, industrial revolution 4.0

\section{INTRODUCTION}

The term of Industrial Revolution 4.0 firstly appeared in 2011 at German, and Angela Merkel, a Germany chancellor introduced it on the meeting of World Economic Forum 2015 (Widiartanto, 2018). Beyond the debates about its ethics and positive or negative impacts from the concept of Industrial Revolution 4.0, experts assume that this Industrial Revolution 4.0 can hardly be eluded. Consequently, people with inadequate abilities to adapt it and its following changes possibly would be not pertinent and survived in this existing age (Marr, 2016).

On the opening ceremony of the Indonesian Industrial Summit 2018 at Jakarta, the Indonesian government stated that they have arranged the roadmap in facing this industrial revolution and established the five industrial categories to be the coming industrial pillars with the purpose of preparing the national competitiveness (Putera, 2018). In relation to the former statement of the national government, this means that the Indonesian government is prepared to face the most recent Industrial Revolution.

Referring to the Industrial Revolution 4.0 phenomena, the National Ministries of Research, Technology and Higher Education (Menristekdikti in Indonesian) responded it to make some breakthroughs and adjustments for preparing the national human resources with qualified competences in the near future. Therefore, the minister has formulated the role models of the ideal educators and the ideal researchers as well as has promoted the growth of the ideal academic leaders at college level. The minister has collaborated with the scientific communities in formulating the basic competence of scholarly disciplines and also the changes on policies and programs relating to the scientific and technological resources of the national higher education institution including the formulation on institutional policies, educational policies, learner affair policies, and as well policies of research and development conducts and innovation conducts
(Kemenristekdikti, 2018). Correspondingly, the national primary education level and the national secondary education level which both function as the early education and learning stage, they must manage the same adjustments on all aspects mainly the adjustments of the method aspects and the learning material aspect that are organized by teachers.

The Industrial Revolution 4.0 phenomena not only produce impacts on the economic sector but also impacts on the human resource sector. The Industrial Revolution 4.0 has been assumed appearing some new problems such as the increasing numbers of the unemployment. Subsequently, schools starting from the primary education level are required to be capable of preparing the generation with competences in adversity and competitiveness in order to challenge all changes from that age.

The primary education is the first level of the mandatory learning programs in most countries on the world including in Indonesia. In 1994, the mandatory learning programs were continued to the nine-year mandatory learning programs consisting of the six-year mandatory learning program and the three-year mandatory secondary learning program (Junior High Education Level). Then, in 2016, the national government presented the twelve-year mandatory learning program with the purpose of providing identical access to education for all Indonesian citizens at the age of 6 to 18 . On the contrary, the twelve-year mandatory learning program has not been yet completely implemented to the present time. For that reason, the national society and the national government should cooperate to make manifestation of the nine-year mandatory learning program (Nuffic, 2015; Unicef Indonesia, 2018).

Regarding to the school numbers, the primary education level schools have achieved greater numbers than the numbers of the secondary education level schools (Junior High Education Level and Senior High Education Level). Economists reported that the 
numbers of the primary schools in 2014 have achieved in the numbers of 170.000 schools at Indonesia, meanwhile the numbers of Junior High Education Level schools are 40.000 and the numbers of Senior High Education Level schools are 26.000. In 2016, the numbers of the primary schools from 34 provinces are rising to 147.536 and the numbers of primary education teachers are 1.648.077 persons as well as the total numbers of the primary education level learners are 25.855.053 persons (BPS, 2017; Kemdikbud, 2017). The data have showed us the important need about the primary education among Indonesians.

According to Sonhadji (2013), the primary education level was the most strategic formal education level since this level laid the foundation on the secondary education level. At the end, this can give influences to the successive education levels. As a result, this paper will discuss about the preparation of the national primary education level institution in challenging the changes of the ages, mainly the changes that brought out by the Industrial Revolution 4.0 age.

\section{METHODS}

A literature review was used as a methodology in writing this paper. Surveys books, scholarly articles, and any other sources relevant to a particular issue, area of research, or theory, and by so doing, provides a description, summary, and critical evaluation of these works in relation to the research problem being investigated. Literature reviews are designed to provide an overview of sources you have explored while researching a particular topic and to demonstrate to your readers how your research fits within a larger field of study.

\section{RESULT AND DISCUSSION}

Nowadays, education in Indonesia is encountered with some critical problems. The problems namely are: (1) the lower equalization in acquiring of the access to education; (2) the lower quality and relevance in education; and (3) the weakness of education management which associated with the absence of independence and the scarcity of eligible knowledge and technologies from the academics.

Globally, a range of organizations are trying to formulate a number of relevant competences and skills in challenging the 21 st century. There is one important thing should be highlighted that educating the youths in the 21 st century hardly accomplished by one approach. Wagner (2010) and the Change Leadership Group from Harvard University identified the competence and adversity skills which were entailed by the learners in challenging the real life, the business world and the citizenship in the 21 st century which focused on the seven important skills as follows: (1) the skills of analytical and problem solved thinking; (2) the skills of collaboration and leadership; (3) the skills of expertness and adaptation; (4) the skills of self-initiation and entrepreneurship; (5) the skills of effective communication in spoken and written language; (6) the skills of access and analysis on information; and (7) having curiosity and imagination.
In relation to the research results from OECD, there were three learning dimensions in the $21 \mathrm{st}$ century, namely information, communication, social ethics and influences (Ananniadaou \& Claro, 2009). Creativity would be one of important elements in challenging the complex world successfully (IBM, 2010).

The US-based Partnership for 21st Century Skills (P21) has identified the necessary competences required in the 21 st century that those were known as the $4 \mathrm{Cs}$, namely communication, collaboration, critical thinking and creativity. The competences were necessarily taught to the learners in the context of the core subject areas and the thematic subjects in the $21 \mathrm{st}$ century. As the result, Assessment and Teaching of the 21st Century Skills (ATC21S) categorize the required skills in the 21st century as the aspects including the way of thinking, the way of working, the tools for working and the skills for living in the world (Griffin, McGraw\&Care, 2012). The framework of thinking is considerably relevant to the education concerns at the present and this can be developed in encountering the issues in the 21st century (Scott, 2015).

Relating to those former opinions and ideas, it can be concluded that one is required not only to cope with knowledge and cognitive aspects, but also to cope with competences and adversities to survive in living within the 21 st century. The competences are included (1) the competence with the skills of communication and socialization in order to survive in a community; (2) the creativity competence with the leadership and entrepreneurship skills and (3) the analysis competence with critical thinking skills.

To answer this, the national primary education level management should create innovations and inventions. Innovations would involve the innovative ways to contend with development as the result of globalization, while inventions or creations would involve intrinsic motivations of all parties who are in charge of the national primary education including the national government in order to change with regard to running those innovations. These changes could be focused on process dimensions in answering the questions of how changes could be performed in order to make the national primary education level as the fundamental base for the learners in challenging the existing era. The question would issue the demands on changing situational aspects involve the innovative ways in actions, new policies, new process and new regulations.

One of the alternatives that could be accomplished by carrying out the changes start from how to make learning not only capable of improving competences but also facilitating the potentials from the learners. Whenever the potentials from the learners could be detected earlier thus, automatically those potentials could be developed further to become the intelligence potential from the learners. Accordingly, the schools should give access to the new learners with any conditions and the schools must observe the condition of the learners psychologically in order to be able to identify the learner's intelligence potentials (Chatib, 2015). 
Learning concept based on multiple intelligence believes that there is no dull learner because every child must possess one certain intelligence potential. Multiple Intelligence based learning is the learning process anchored in a range of human intelligences that those would be classified into eight human intelligences such as the intelligences of linguistic-verbal, the mathematical intelligences, the visual-spatial intelligences, the kinaesthetic intelligence, the musical intelligences, the intrapersonal intelligences, the interpersonal intelligence and the naturalist intelligence (Gardner, 2003).

Multiple intelligence-based learning involves the learners to learn through activities as the essential pillars in constructing knowledge, emotions, motivations and skills. Along with Dewantoro (1997) who has given definitions that education as an effort to improve the growth of the children's character building, intellectuality, and physical body in attaining the perfect and harmonious living with the children's world.

According to Ahmed (2012), the multiple intelligence based learning has advantages as follows: (1) to recognize that there would be a range of ways becoming "intelligent"; (2) to obtain equal position on all intelligence forms; (3) to build appreciation on individual since the learner build his strength and hardworking becoming expert on certain subject of intelligence; (4) to build a solid problem solving skill that it can be applied in the real life situation.

Furthermore, some studies showed that managing learning management can be accomplished to contribute some improvements and impacts on the education outputs as one of the studies conducted by Nair and friends (2011) which indicated the impact of management systemic learning approach on the learners during the learning process. Likewise, there would be learning models as methods in developing learning process. Winarno (2009) also stated that the standard competences as the learning goals should be adjusted with the learning materials and the method of teaching by the teachers.

Relating the primary education to the national preparation in challenging the Industrial Revolution 4.0 would be gone too far. But, relating the function and purposes of the national primary education as the fundamental base to the national successive education level wherein learner would be able to reach the highest level of The Indonesian National Qualification Framework (KKNI) as an expert not as the idea which beyond imagination indeed. The primary education could be focused on constructing and implanting character building, intellectuality competences, cultures, physical and mental health from the learners. Implanting those since the early age of children could influence the characters of individuals at their coming productive ages and finally, these could determine the nation's characters.

\section{CONCLUSION}

The national primary education has strategic roles in building the human resources to challenge the changes of ages. The scientific and technological development (IPTEK) could influence the development on all living sectors including education sector. The existence of Industrial Revolution 4.0 is the manifestation of the rapid development from informational society. In the informational society, the most vital resources are information and knowledge.

The Industrial Revolution 4.0 challenges could be encountered with the management of changes on the national primary education in the forms of innovations and inventions. These could be manifested through multiple-intelligence-based learning that accommodate the learners' potentials with a set of intelligence and need the supports of the principles' and teachers' roles into their learning management.

\section{REFERENCES}

[1] Ahmed, G. A. 2012. The Relation between Multiple Intelligences Theory and Methods of ELT. International Journal of Learning and Teaching, 4(2), 26-41.

[2] Ananiadou, K., and Claro, M. 2009. 21st Century Skills and Competences for New Millennium Learners in OECD Countries: OECD Education Working Papers. Paris: OECD Publishing.

[3] Badan Pusat Statistik. 2017. Jumlah Sekolah, Guru, dan Murid Sekolah Dasar (SD) di Bawah Kementerian Pendidikan dan Kebudayaan Menurut Provinsi Tahun Ajaran 2011/2012-2014/2015. Retrieved April 26, 2018, from https://www.bps.go.id/.

[4] Chatib, M. 2015. Sekolahnya Manusia: Sekolah Berbasis Multiple Intelegences di Indonesia. Bandung: Kaifa Learning.

[5] Dewantara, K. H. 1977. Pendidikan. Yogjakarta: Majlis Luhur Persatuan Taman Siswa.

[6] Gardner, H. 2003. Kecerdasan Majemuk (Multiple Intelegences): Teori dan Praktik. Batam: Interaksara.

[7] Marr, B. 2016. What Everyone Must Know About Industry 4.0. Retrieved April 26, 2018, from https://www.forbes.com.

[8] Nair, K. 2011. Enhancing Learning ang Teaching Through Student Feedback. European Journal of Engineering Education, 36 (1), 3-12.

[9] Nuffic. 2015. Education system Indonesia 2nd. Retrieved April 26, 2018, from www.nuffic.nl. (Online).

[10] Putera, A. D. 2018. 5 Industri Utama Disiapkan untuk Revolusi Industri 4.0. Retrieved April 26, 2018, from https://ekonomi.kompas.com.

[11] Scott, C. L. 2015. The Futures of Learning 2: What Kind of Learning for the $21^{\text {st }}$ Century? UNESCO Education Research and Foresight, Paris. [ERF Working Papers Series, No. 14].

[12] Sonhadji, A. K. H. 2013. Manusia, Teknologi, dan Pendidikan Menuju Peradaban Baru. Malang: UM Press.

[13] The Economist. 2014. Education in Indonesia School's in. Retrieved April 26, 2018, from https://www.economist.com.

[14] UNICEF Indonesia. 2018. The School Years. Retrieved April 26, 2018, from https://www.unicef.org/indonesia/children_2833.html.

[15] Widiartanto, Y. H. 2018. Revolusi Industri 4.0 Memangkas Sekaligus Memunculkan Pekerjaan Baru. Retrieved April 26, 2018, from https://ekonomi.kompas.com.

[16] Winarno. 2009. Pembelajaran Multimedia. Bandung: Genius Prima Media. 